\title{
Paul Samuelson's Historiography: More Wag Than Whig
}

\author{
E. Roy Weintraub
}

Duke University

November 4, 2015

ERID Working Paper Number 197

This paper can be downloaded without charge from the Social Science Research Network Electronic Paper Collection:

http://ssrn.com/abstract=2686657

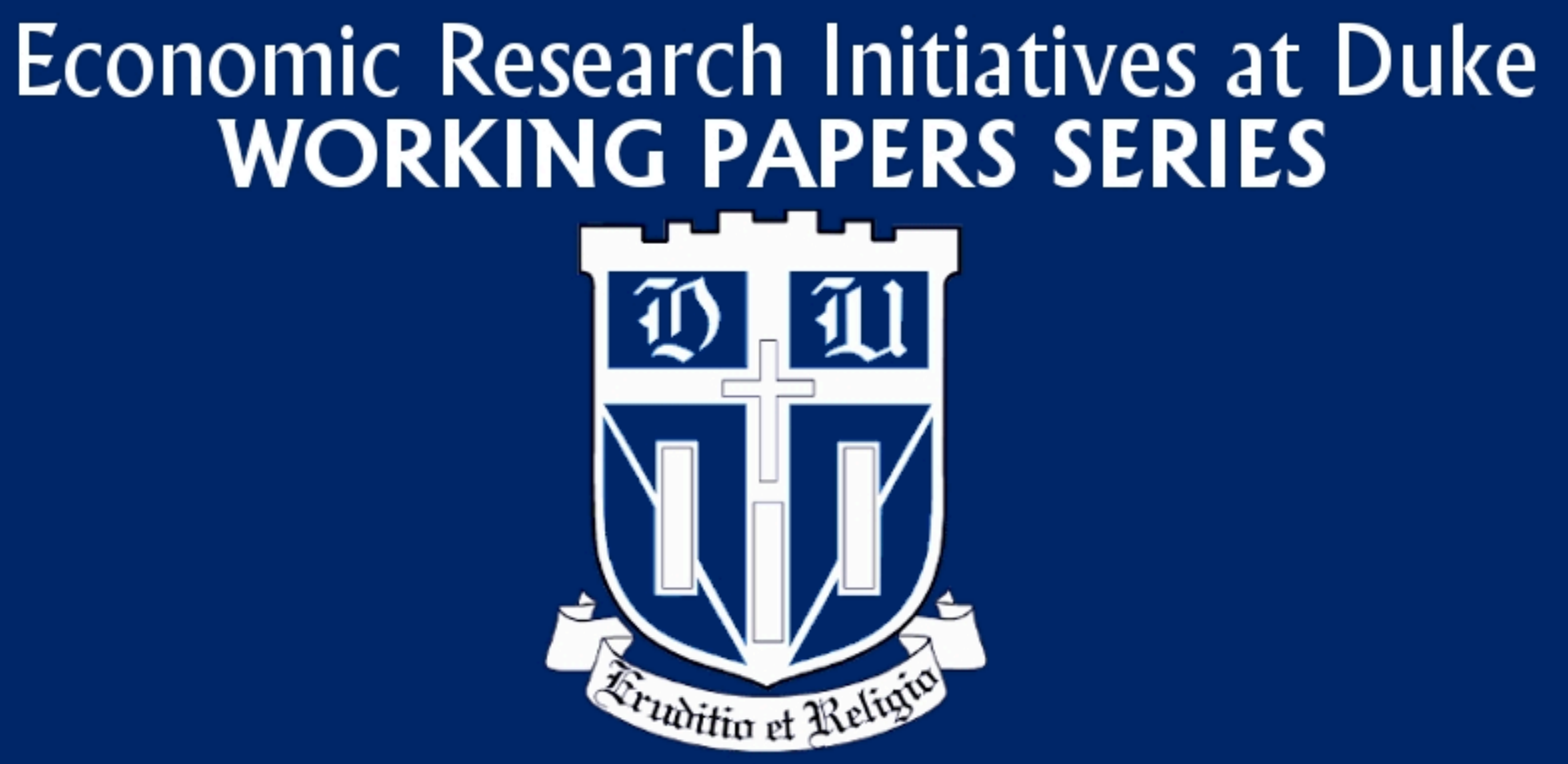




\section{Abstract \\ Paul Samuelson's Historiography: More Wag Than Whig}

By E. Roy Weintraub, Duke University

In this review essay of Medema's and Waterman's collection of some of Samuelson's writings in the history of economics, the author argues that Samuelson's claim to have written "Whig History" is spurious. Moreover the author argues that Samuelson's own writings on modern economics are, whether explicit or not, profoundly autobiographical. Samuelson, in constructing a literature ostensibly about contemporary economics, was simultaneously constructing a literature in which he and contemporary economics could be jointly considered and appraised.

JEL Codes: B00, B1, B2, B3, D00, E00, N00

Keywords: Paul A. Samuelson, historiography, Whig History, autobiography, history of economics 


\section{Paul Samuelson's Historiography: More Wag Than Whig}

Paul Samuelson on the History of Economic Analysis. Eds. Steven G. Medema and Anthony M. C. Waterman. New York: Cambridge University Press, 2015. x +466 pp.

Mark Blaug's 1991 edited volume, The Historiography of Economics, collected fourteen articles by different authors exploring the ways in which the history of economics had been (or not been) valued, how it had been written, what were its objectives and audience, and potential role in a future community of economists. Most of the articles were written in the 1960s through the 1980s, a time during which the history of economics established itself as a subdiscipline of economics. The founding of the journal History of Political Economy was quickly followed by the organization of the History of Economics Society. Those institutional changes, decried by Lord Robbins, linked scholars who previously had thought of themselves primarily as economists with a side interest in historical texts. But as Blaug's contributors saw matters, by 1991 it was becoming clear that nothing would be able to arrest the field's rapid marginalization. North American historians of economics realized that there were few young economists with historical sensibilities in the professional pipeline since departments of economics had been dropping requirements that economics students, graduates and undergraduates, take courses in the history of economics. With fewer new teachers of the subject, there would be fewer courses offered, and thus the demand for such teachers would fall pari passu. Many of the papers in the Blaug volume worried that theme. 
Donald Gordon noted "I have taken an informal poll of those departments which produce the mass of doctoral degrees in our field. The results, ... indicate a decline in the interest in this area" (119). Kenneth Boulding wrote about "the anti-historical school, which is now common in the United States, where the history of thought is regarded as a slightly depraved entertainment, fit only for people who really like medieval Latin, so that one can become a full-fledged, chartered Ph.D. economist without ever reading anything that was published more than ten years ago" (100). In an especially cogent piece, Warren J. Samuels argued that the history of economic thought both was and should be connected to intellectual history more generally. At the same time Robert Heilbroner began his paper by stating that "the history of economic thought is not in very high esteem these days. Few universities include it as a prescribed portion of the standard training curriculum for budding economists" (134), a claim that echoed Filipo Ceserano's that "It is a widely held opinion among economists that the history of the subject is of little relevance to the present day scholar. This opinion is reflected in the sharp decline of interest in the history of economics" (63).

The thirteenth contribution to Blaug's volume was Paul A. Samuelson's provocative essay "Out of the Closet: A Program for the Whig History of Economic Science". Reprinted from the History of Economics Bulletin (1987), the predecessor of the Journal of the History of Economic Thought, it had been given as the Keynote Address to the History of Economics Society at its meeting in Boston on June 20,1987. Samuelson responded to the worries of historians of economics by outlining a strategy for recapturing the interest of economists in the history of economic thought. Quite simply, historians should write for the audience of economists, not historians. He believed that such an approach was a natural one since all of economics analysis, from the classics to the modern period, was concerned with problems that, 
given the conceptual unity of economic analysis, could be informed by modern economics. The past should be written for economists from the perspective of modern economics. The past was prelude, and the present analyses grew from the older analyses. The implication was clear: to write about past economic thought, one had to present those ideas in modern dress, and to appraise past work, one had to judge it on its merits as good economic analysis as we today know it. Blaug later characterized this mind set as "No History Please, We're Economists" (2001).

In the new volume Paul Samuelson on the History on Economic Analysis: Selected Essays, edited by Steven G. Medema and Anthony M. C. Waterman (2015), Samuelson's 1987 essay appears as the first selection immediately following the editors' Introduction. His 1987 call to action, and the editors' general introduction to the seventeen selected papers, raises complex questions that historians of contemporary economics have mostly sought to avoid. In what follows, I will eschew avoidance and raise a set of questions that may serve to reinvigorate what has become a tiresome series of laments about, and defenses of, the history of economics.

Searches of Google Scholar and JSTOR suggest that citations to Samuelson's 1987 piece occur from time to time, but there has been little recent engagement with its primary argument. Samuelson, whom I believe to be the most important American economist of the twentieth century, needs no defense of either his intellectual acuity or activity. He wrote on topics directly and indirectly associated with the history of economics over his entire career and as the editors point out, "Nearly 140 articles, essays, or memoirs listed at the end of [our] volume appearing over a period of forty-four years from 1946 to 2009 and comprising perhaps 20 percent of his scholarly publications, are clearly identifiable as studies of the history of economic thought." I doubt that many self-identified historians of economics have a publication record as long and 
varied. The authors' introduction offers an appraisal of Samuelson's work in the area. One paragraph gives what, to this reader, is the central point to keep in mind when reading these seventeen papers by Samuelson. Though it is long, I will quote it in full because it raises most of the questions that the rest of my essay seeks to answer.

Samuelson occupies a controversial place among historians of economics. Because of his vision of the conceptual unity of all economic analysis, his historiographic method when reaching deep into the past was to formalize the analysis of his predecessors (and he saw them as such) using modern mathematical tools and theoretical constructs. Contextual elements such as historical background, influences, and ideology - important to most other historians - were ruthlessly ignored. When we move closer to the present, however, and witness Samuelson analyzing the work of contemporaries and near-contemporaries through what he described as a historical lens, we see a different approach, one that brings in the role of personalities, context, and scholarly communities in the creation of path breaking ideas - that is, invoking elements of history that, as we shall see in this volume, he tended to dismiss in certain of his commentaries on writing the history of the economics of the distant past. (5)

This "formalization of the analysis of his predecessors" is central to most of the discussions of Samuelson's work in the history of thought. Samuelson himself, as the editors 
note, defended this approach by identifying it as "Whig History of Economic Science." This is Samuelson the neologist who coined "the Neoclassical Synthesis", "the Correspondence Principle", "the Theory of Revealed Preference" and so on. However his deployment of Herbert Butterfield's book The Whig Interpretation of History (1965 [1931]) shows a remarkable lack of understanding of Butterfield. That distinguished historian was arguing that a political history was Whiggish if its organizing narrative structure showed that the moves of the various historical actors, their actions, and events represented progress or progressive moves. Progressive moves were characterized as presentist, projecting our present ideas back into the past and there finding "precursors", "antecedents" and the like. A Whig history was a history of progress. This, Butterfield argued, was misleading. He explained that

Real historical understanding is not achieved by the subordination of the past to the present, but rather by making the past our present and attempting to see life with the eyes of another century than our own (16).

And he concluded his short book by reminding us that

[The] truth of history is no simple matter, all packed and parcelled and ready for handling in the marketplace. And the understanding of the past is not so easy as it is sometimes made to appear (132).

Samuelson argued for the conceptual unity of economics, so that the same conceptual framework that guides work today can be projected back onto Adam Smith, David Ricardo, Robert Malthus, John Stuart Mill, Karl Marx, etc. The conceptual unity argument, constrained optimization and all that, was the central feature of Samuelson's Foundations of Economic 
Analysis (1947). That book launched many of the modernizing moves in postwar economics and provided the foundation of Samuelson's luminous intellectual career.

What Samuelson's claim does not do however is distinguish his work as history in any interesting fashion. Samuelson used historical materials just as he might have used materials from today's Wall Street Journal. His interest was in applying the tools of modern economic analysis to understand, to model, to develop an approach to thinking about, a particular problem that the text suggested. The "Canonical Classical Model", the "Tableau Economique", paying for public goods like bridges, all such were to be treated symmetrically. Samuelson was a brilliant economic theorist and analyst, and his approach was normal MIT economic practice. As was discussed in a number of places in the volume MIT and the Transformation of American Economics (Weintraub 2014), MIT in the Samuelson years developed a distinct way of doing economics. It involved simplifying the problematic, stripping it of details that distracted from what the economist believed were the salient issues, and analyzing the "small" models. Samuelson's colleague, Robert Solow, in his 1969 Radcliffe Lectures, laid out the method in detail:

There are always aspects of economic life that are left out of any simplified model. There will therefore be problems on which it throws no light at all; worse yet, there may be problems on which it appears to throw light, but on which it actually propagates error. It is sometimes difficult to tell one kind of situation from the other. All anyone can do is to try honestly to limit the use of the parable to the domain in which it is not actually misleading, and that is not always knowable in advance (Solow 1970, 2). 
What Samuelson was doing in his studies of classical authors was precisely this: he was using their texts to construct simple models that appeared tractable and could be mapped back onto some small element of the authors' interest. Samuelson was not doing Whig history. Samuelson was performing economic analysis.

Using Butterfield's framework, the history of science as most all scientists see it is a story of movement from darkness to light, from ignorance to knowledge. It is a story of progress. As scientists talk science among themselves, and as they seek to control public discussions of scientific work, they behave Whiggishly. Believing as they do that their job is build on past work, to create new knowledge, scientists are socialized to think Whiggishly when they function as scientists. Since the early 1940s, when mainstream economists began to see themselves as doing "economic science" instead of "political economy", their working mind set has been similarly Whiggish. But the history of science is not preformed in science departments. So too the history of economic science is not preformed much, if at all, in North American economics departments. This fact is a necessary and irreversible result of economics becoming a serious science. Despite the protestations of those who bemoan the scientific turn, despite the complaints of non-mainstream economists about the wrong turns of the discipline, economics will not revert to its earlier practices.

"Whig history" is a monumental distraction. The phrase's use compels readers to believe that Samuelson was writing some sort of history. He was doing nothing of the kind. It was a manifestation of Samuelson's own remarkable ability to "see" simple and tractable models in the works of older economists just as he saw simple and tractable problems in discussions of both economists and our economic life. Such "seeing" was remarkable, and Nobel-worthy. That he 
enjoyed such work is indisputable. It allowed him to engage with a large number of scholars who were not fellows of the Econometric Society. Biographical studies currently emerging (Backhouse, to appear) show that he was a joyful conversationalist, and we have the evidence of his voluminous correspondence to show exactly how he engaged scholars of all sorts. Looking at older texts enabled him to extend his reach and his networks. This was reasonable behavior for an individual who was trained in the 1930s at the University of Chicago, a place where the great books had taken root. As the editors point out, even the Foundations of Economic Analysis, mostly written in the $1939-44$ period, is replete with references to classic works of the $18^{\text {th }}$ and $19^{\text {th }}$ century. That is how theory was written in those days. Samuelson as a modern economist saw such older works as "problems" to be solved, and his natural instinct was to apply modern methods to their solution. But retrospectively to characterize such work as Whig history is to throw historiographers off the scent.

As mentioned earlier, Medema and Waterman show how, as Samuelson's texts and investigations move closer to the present, the methods he employed changed radically. There is however an identification problem here. What the editors take to mean "closer to the present" really means what is usually termed contemporary economics. In other words, Samuelson's historiography of contemporary economics differs markedly from the modeling method he employed for understanding "older economics". The difficulty is that Samuelson helped to create contemporary economics. If as is now usual we date the transformation of economics into a scientific discipline from the late 1930 s to the early $1950 \mathrm{~s}^{1}$, a large if not compelling reason for

\footnotetext{
${ }^{1}$ Some would argue that the 1940s were nearly the end of that transition. They claim that $\mathrm{t}$ he beginning is the mid-19th century, where the ambition is absolutely clear in Jevons, its having already been clearly adumbrated nearly 30 years earlier in Mill; is embodied in Marshall's of Economics and in John Neville Keynes's methodology book in the 1890s; and is strenuously restated in Robbins's Nature and Significance of Economic Science. The point is contentious, but in my view the
} 
that shift was Samuelson's own work. Winner of the first John Bates Clark award in 1947, Samuelson was the very model of the modern new economist, comfortable with new ideas in economic policy (e.g. Keynesian economics) and conversant with the language of mathematics and statistics. He wanted to change how economists were trained, and what it meant to be a modern economist, founding the economics Ph.D. program at MIT in 1940.

Samuelson's immense and extensive correspondence with economists of the postwar generation shows him to be a spider at the center of a web, a network, of all those who were, like him, changing the nature of economics in the postwar decades. Samuelson reminds one of Alfred Marshall who controlled the British economics profession from Cambridge. His files contain an enormous number of letters of reference, appraisals of job candidates, and responses to requests for names of individuals' qualified to receive various awards for merit. It is no accident that his list of potential Nobel laureates, delivered to the Nobel committee two years before the award of any prizes in economics, contained most of the winners in the first dozen or so years following the prize's creation.

But if economics became a science in the postwar period, Samuelson's way of writing the history of contemporary economic science itself had to be different from his modeling the classics. Modeling those sequences of models that characterize today's discipline of economics can hardly historicize the discipline. It is simply silly to model a sequence of models.

The history of science is well-established. ISIS, the journal of the History of Science Society, was founded by George Sarton in 1924, and books on its historiography of science (e.g. Kuhn 1962; Kragh 1987; Golinski 1998) are well known. Many historians of economics know

earlier figures represented a "call to arms". But it was only into the 1940s that the army was actually raised. 
that the history of science was revolutionized in the 1970s and 80s by "science studies" which intertwined the history of science with the sociology of scientific knowledge. The emergent epistemological turn questioned the earlier assumptions about how science "worked". That literature is too immense to discuss here (although Golinski (1998) is helpful). The 1995 volume 10 of Osiris, published by the History of Science Society and edited by Arnold Thackray, was titled Constructing Knowledge in the History of Science, and its contributors judiciously appraised the major post-Kuhn conflicts about how to write the history of science. Other than my work (1991; 1999), and that of Philip Mirowski (1989; 2002), Esther-Mirjam Sent (1998) and Robert Leonard (2010), there are few counterparts in the history of economics. Apart from say Backhouse and Fontaine (2014), there is little awareness of the connection between the science studies movement and the historiography of economic science.

The difficulty is that many historians of economics do not seem to understand the difference between contemporary economics and pre-World War II economics. Writing the history of pre-World War II economics often involves reading and interpreting texts, books in the canon, arguments made by members of particular schools of thought, and so on. Once economics developed its own professionalized scientific discourse, its own rhetorical strategies, the actual written productions of economists became more formulaic. It is one thing to look askance at the standard set of instructions given to today's economics graduate students about how to construct a publishable paper, but it is another thing to take the published papers that result and treat them as informative historical documents open to conflicting interpretations. Reading Debreu's Theory of Value the way one reads The Wealth of Nations may be interesting as a study in style and rhetoric, but it reveals nothing of its history to its reader (Düppe 2012; Düppe and Weintraub, 2014). In contrast Keynes's General Theory intertwined its analysis with 
discussion of the historical circumstances that produced it. The same cannot be said about Samuelson's “The Pure Theory of Public Expenditure". How then is one to write the history of contemporary economic science? This is a question that, with two exceptions, my own (1999) and A. W. "Bob" Coats (2003), no one in the history of economics community has addressed.

Recently in their 2014 A Historiography of the Modern Social Sciences, editors Roger E. Backhouse and Philippe Fontaine collected informed discussions about both specific historiographic approaches and more general historiographic developments in post WWII social science disciplines. Their contributors' observations about the similarities and differences in the several fields framed their own discussion about economics. They were not very optimistic about the future:

Despite the opening up of the history of economics to the history, philosophy, and sociology of science and to a lesser extent to history, most work in the field continues to follow more traditional paths... While some would like to see the lack of a clear identity for the field as a sign of its liveliness, richness, and even strength, it may equally be taken as the expression of its very uncomfortable position within academe (204).

Medema and Waterman engage this problem only indirectly. In my view though it is the centerpiece of their volume. That is, they argue quite directly that when Samuelson wrote about more contemporary economics, he became much less formal in his treatments. What they show is that he wrote memoirs, autobiographical bits, obituaries, reminiscences, recollections, tributes, and evocations of place in many different circumstances. The editors assert that these pieces are rightly considered to be contributions to "the history of economics". 
I believe they are nothing of the sort. These are the raw materials of history comparable to Samuelson's performing his own oral history of, say, the University of Chicago in the 1930s. As autobiographical accounts, recollections of encounters with those whom he is writing about, Samuelson of course is no more trustworthy than any eyewitness. Often we historians can use such memorials as the raw materials in constructing histories, even though they need to be checked against other materials that may or may not conform to them (Weintraub 2005). An excellent example of this is Samuelson's own recollections (1998) about the difficulties he faced in getting The Foundations of Economic Analysis into print. We now know (Backhouse 2015) that he misremembered the print run of the book, the time sequence of events leading to publication of the book, and what happened to the plates for the book after publication. Framing historical questions and providing tentative answers in a coherent narrative is the job of the historian of contemporary economics. These are not problems that can be addressed in the same way that an historian might address disparate interpretations of Ricardo's "On Machinery".

Economists, or historians of economics, appear to be unaware that there are very sophisticated discussions in the history of science about how to construct and develop histories of contemporary science. The works of Thomas Söderquist, for example The Historiography of Contemporary Science and Technology (1997), The Historiography of Contemporary Science, Technology and Medicine (with Ronald Doel, 2006), and Science as Autobiography (2003) are path-breaking studies concerned with exactly these issues.

Most historians of contemporary (post-World War II) economics develop their histories of, say, the rational expectations movement, or the history of the monetarist counter-revolution, or the decline of Keynesian economics, as narratives in which they provide explications and interpretations of the actors' scientific contributions. The problem is that many of these studies 
are little more than survey articles cast back in time. Some of the authors writing history take as their model Mark Blaug's useful volume The Methodology of Economics (1980) which examined general equilibrium theory, human capital theory, the economics of education, and so on. But instead of historical appraisals and reconstructions of these literatures he provided instead methodological reconstructions. That is, in that volume, he characterized these theories in economics as Lakatosian scientific research programs. While this made comparisons among the theories possible, it wasn't history. That book's divorce of history of economic science from philosophy of economic science seems to have been the origin of Blaug's own confused attempts to distinguish rational reconstructions from historical reconstructions in writing the history of modern economics, ideas he picked up from Quentin Skinner and Richard Rorty. What he did not seem to appreciate was that those ideas were developed in the context of the history of political theory, or intellectual history more generally. They did not come from the history of science $^{2}$. Discussions of the merits of historical versus rational reconstructions are irrelevant to writing histories of contemporary economics.

Consider the problem of writing a history of human capital theory. What might a rational reconstruction look like? One first needs to ask: who is that history written for? Since most doctoral dissertations and articles in the history of economics have, as their primary audience, economists with an interest in the history of economics, the history would be directed toward clarifying for other economists the development of ideas in human capital theory. The standard narrative strategy would involve examining terms, seeking the filiation of ideas, and ultimately providing an appraisal of the human capital literature. If one has difficulty understanding

\footnotetext{
${ }^{2}$ It is reasonable to believe that Blaug, who esteemed Imre Lakatos, took some of his views from "History of Science and Its Rational Reconstructions", the second chapter of The Methodology of Scientific Research Programmes (1978).
} 
particular papers in the human capital literature, explaining those papers in terms of a sequence of rational moves by author-actors would seem to be a necessary rhetorical strategy. But how is this distinguishable from a survey?

What would an historical reconstruction look like? It could employ a number of methods, or rhetorical strategies: it might employ network or actor-network analysis, or perhaps prosopography, perhaps letters and correspondence of the actors, lecture notes and exams and reading lists, accounts of both success and failure in responses to the new ideas examined through referee reports, funding requests and grant acceptances and rejections, questions at conferences, and so on. It might also seek to contextualize the central metaphor of human capital itself as an attempt to displace narratives in which consumption is the end of human activity in favor of ideas associated with economic growth. Questions of economic development could be brought together with the human capital literature in order to frame studies of how to increase growth and prosperity in less developed countries, a trope that came to figure prominently in the growth stories of the 1960s. And so on. But this isn't "historical reconstruction". It's history.

Attempts to push the discussion of how to write history of economics onto axes of historical and rational reconstruction are spurious. Those distinctions, together with Samuelson's faulty appropriation of the idea of Whig history, have left some very good historians of economics quite confused. Those who are not confused include historians of science, particularly the new generation of historians of postwar social science (e.g. Angus Burgin, Paul Erickson, Hunter Heyck, Joel Isaac, Mark Solovey, William Thomas, et al.) who have been encamping more and more comfortably on terrain that historians of economics had called their own. Historians of economics who wish to argue about whether the human capital model is antifeminist, or whether Keynes's theory is misunderstood by modern macroeconomists, are 
attempting to persuade fellow economists of one or another argument that matters to economists. Historians of science could not care less whether Keynes' theory has Walrasian or Marshallian roots. They're interested instead in understanding the context in which say macro-econometrics developed in the immediate post-World War II period and not whether Tinbergen or Keynes had the correct opinion of econometrics.

For a short period of time there were some works in the history of economics that engaged the new history of science (e.g. Mirowski 1989, 2002; Weintraub 1991, 2002; Sent 1998). While this work was widely praised, it was not widely imitated. It is still the case that many historians' studies of the contemporary period appear to be, as Bruno Latour once noted, "legends of the saints". The cascade of interviews of the Nobel laureates, the possible future laureates and important economists, and so on suggest that the kind of writing that Samuelson did about contemporary economists is and will remain paradigmatic for economists constructing their own historical legacy.

Samuelson's writings on contemporary economists, most all of whom he knew personally, are drawn in the same fashion as Keynes' Essays in Biography, and his obituary notices in The Economic Journal. Samuelson, because of his wit and his connections and his opinionated writing style, composed a very large number of these mini-biographies and remembrances. It is a genre quite distinct from his work on the classical model, or Marx's Theory of Capital. They are closer to the kind of writings discussed in Backhouse's (2007) examination of short biographies of economists than they are to histories of postwar economics.

The editors are cautious, in my view overcautious, in attending to what Samuelson had to say about Samuelson the historian. Nevertheless the places in their Introduction where they step back and look at his writing history are on very solid ground. They observe quite correctly 
"Samuelson located the study of the history of economics, and the audience for such studies, in the economics profession rather than among historians" (7). They make clear that Samuelson's writings about his contemporaries and near contemporaries, and the development of particular schools of economic analysis is "staggering: more than 80 articles spanning a period of roughly 50 years" (8-9). They show that "Samuelson's attitude towards contextual elements and the like was very different when he was considering the work of contemporaries and near contemporaries than it was when he was working with the ideas of the distant past. When it comes to the history of twentieth century economics, Samuelson was writing as a participant-observer..." (9).

I do not agree however with their claim that those writings on contemporary economics "are both historical analyses in and of themselves and the source of a treasure trove of data for other historians of modern economics. They also reveal that there is far more to Samuelson as a historian of economics than the translation of the ideas of the past into modern mathematics" (10). I believe instead that Samuelson, in every one of his writings on his contemporaries or on the contemporary scene, was performing autobiography.

Samuelson's correspondence files reveal that he was always writing with a view to posterity and his place in the pantheon. He was immensely concerned with how historians would write about him, and his papers contain folders with historians' names on them showing his concern for how he would be treated by posterity. His casual cutting remark on an individual contemporary economist works not simply to give the listener/reader his view of that contemporary's place in economics but also provides Samuelson's opinion of that place vis a vis his own. I cannot emphasize this too strongly. Samuelson, in constructing a literature about contemporary economics, was simultaneously constructing a literature in which he and contemporary economics could be jointly considered. To leave this element out of a discussion 
of Samuelson's historiography is to miss a major opportunity to see how the autobiographical impulse in Samuelson was manifest. Consider that Volume 7 of his Collected Scientific Papers contains Part X, Autobiographical Writings. There are twenty-three articles there, not one of which appears in the Medema and Waterman volume. The editors state that Cambridge University Press was unwilling to reprint papers from that most recent volume of the Collected Papers. This itself reflects poor editorial judgment by the Press since all of the papers collected by Medema and Waterman have in fact appeared somewhere in Volumes One through Six. His autobiographical papers are numerous and sometimes are written in the third person: the same story appears first in one place, then in another, then in a third all with slight variations to demonstrate how his own observations and experiences were important to understand the subject at issue. To present an egoless Paul Samuelson is, for those who knew him or worked with him, to miss an essential characteristic of the man. As Robert Solow recalled, "Paul once overheard a young colleague's remark that whenever Larry Summers walks into a room, he is the smartest person in it. Paul interjected 'Yes, unless one of his uncles is there."' He never stopped measuring himself and the measuring rod was, for his scientific life, an historical one. His histories were not disinterested. But neither are they unimportant.

\section{E. Roy Weintraub, Duke University}

\section{References}

Backhouse, R. E. (2007). Lives in Synopsis: The Production and Use of Short Biographies by Historians of Economics. Economists Lives: Biography and Autobiography in the History of Economics. E. R. Weintraub and E. L. Forget. Durham NC, Duke University Press: 51-75. 
Backhouse, R. E. (2015). "Revisiting Samuelson's Foundations of Economic Analysis " Journal of Economic Literature 53(2).

Backhouse, R. E. and P. Fontaine, Eds. (2014). A Historiography of the Modern Social Sciences. New York, Cambridge University Press.

Backhouse, R. E. and P. Fontaine (2014). Contested Identities: The History of Economics since 1945. $\underline{\mathrm{A}}$ Historiography of the Modern Social Sciences. R. E. Backhouse and P. Fontaine. New York, NY, Cambridge University Press: 183-210.

Blaug, M. (1980). The Methodology of Economics. New York, Cambridge University Press.

Blaug, M., Ed. (1991). The Historiography of Economics. Brookfield VT, Edward Elgar.

Blaug, M. (2001). "No History of Ideas, Please, We're Economists." Journal of Economic Perspectives 15(1): $145-164$.

Butterfield, H. (1965 [1931]). The Whig Interpretation of History. New York, Norton.

Coats, A. W. (2003). The Sociology of Economics and Economic Knowledge. A Companion to the History of Economic Thought. W. J. Samuels, J. A. Biddle and J. B. Davis. Malden MA and Oxford, Blackwell: 507-522. 
Doel, R. E. and T. Söderquist, Eds. (2006). The Historiography of Contemporary Science, Technology and Medicine.

Düppe, T. (2012). "Gérard Debreu's Secrecy: His Life in Order and Silence." History of Political Economy 44(3): 413-449.

Düppe, T. and E. R. Weintraub (2014). Finding Equilibrium: Arrow, Debreu, McKenzie and the Problem of Scientific Credit. Princeton NJ, Princeton University Press.

Golinski, J. (1998). Making Natural Knowledge: Constructivism and the History of Science. New York and Cambridge, Cambridge University Press.

Kragh, H. (1987). An Introduction to the Historiography of Science. New York, Cambridge University Press.

Kuhn, T. S. (1996 [1962]). The Structure of Scientific Revolutions. Chicago, University of Chicago Press.

Lakatos, I. (1976). Proofs and Refutations. Cambridge and New York, Cambridge University Press.

Lakatos, I. (1978). The Methodology of Scientific Research Programmes. New York, Cambridge University Press. 
Leonard, R. L. (2010). von Neumann, Morgenstern, and the Creation of Game Theory. Cambridge and New York, Cambridge University Press.

Mirowski, P. E. (1989). More Heat Than Light. New York and Cambridge, Cambridge University Press.

Mirowski, P. E. (2002). Machine Dreams. Cambridge, Harvard University Press.

Samuelson, P. A. (1947). Foundations of Economic Analysis. Cambridge, Harvard University Press.

Samuelson, P. A. (1998). "How Foundations Came to Be." Journal of Economic Literature 36(3): 13751386.

Sent, E.-M. (1998). The Evolving Rationality of Rational Expectations: An Assessment of Thomas Sargent's Achievements. Cambridge and New York, Cambridge University Press.

Söderquist, T., Ed. (1997). The Historiography of Contemporary Science and Technology. Amsterdam, Harwood Academic Publishers.

Söderquist, T. (2003). Science as Autobiography. New Haven, Yale Universirty Press.

Solow, R. M. (1970). Growth Theory: An Exposition. Oxford, Clarendon Press. 
Thackray, A., Ed. (1995). Osiris Vol. 10: Constructing Knowledge in the History of Science. Chicago, University of Chicago Press.

Weintraub, E. R. (1991). Stabilizing Dynamics. New York, Cambridge University Press.

Weintraub, E. R. (1999). How Should We Write the History of Twentieth Century Economics? Oxford Review of Political Economy 15(4): 139-152.

Weintraub, E. R., Ed. (2002). The Future of the History of Economics. Durham NC, Duke University Press.

Weintraub, E. R. (2005). "Autobiographical Memory and the Historiography of Economics." Journal of the History of Economic Thought 27(2).

Weintraub, E. R., Ed. (2014). MIT and the Transformation of American Economics. Durham NC, Duke University Press. 